\title{
Non-standard Idioms in Cameroon English Literature and Their Impact on English Language Learning and Intelligibility
}

\author{
Lozzi Martial Meutem Kamtchueng \\ Department of Bilingual Letters, University of Maroua, Cameroon
}

\begin{abstract}
Drawing data from fifteen works of seven Cameroonian writers of English expression, this paper examines non-standard idioms in this area of English language use laying emphasis not only on the various processes via such idioms are created but also on their impact on English language learning as well as on intelligibility. The findings of the study reveal that these non-standard idioms are obtained via the translation of home languages expressions, coining and modification of Standard British English expressions. Besides, it is argued in the paper that given that in the Cameroonian educational system, English language learners are tested on the basis of native English models, these non-standard idioms can be counterproductive to the learning of English language as well as on the intelligibility of the writers with their readership. The paper intends to contribute to the ongoing debate about the problematic concerning the consumption of non-native English literary works.
\end{abstract}

Index Terms - non-standard idioms, language learning, intelligibility, native English model, non-native English literary works

\section{INTRODUCTION}

A certain number of features called non-standard features in Cameroonian literary productions which could be counterproductive to the learning of English language by the readers of these literary productions have been explored in Ayafor (2011). They include the following: tense inconsistencies (e.g. "people said she will become a big woman"), dangling modifiers (e.g.: "Being brilliant in her school her father had worked hard on his farms), omission of coordinating conjunctions (e.g. "Sanitation was divided into two main groups: cleaning around the compounds and repairing latrines, cleaning the paths..."), use of infinitive instead of modal auxiliary (e.g.: "For now, she should be counted out of the selection and the first to stand), unnecessary insertion of "to be" (e.g.: "It is the Lord God that made us to be what we are today"), incorrect past participle of verbs (e.g.: "The hospital had ran smoothly"), use of verb + adjective instead of verb + noun (e.g.: Children brought up in righteousness can only breed good"), comma splice (e.g.: "Ngwe was restless, she could imagine the joy and happiness..."), wrong use of apostrophe (e.g.: Now I am able to help my junior one's in primary school"), problem of phrasal verbs (e.g.: "[...] she would leave the house and never arrive the center"), wrong use of preposition (e.g. "[...] she dreamt that she was admitted in a university"), vocative not separated (e.g.: "That is a very progressive way of looking at life my daughter"), run-on sentence (e.g.: "But there is something you must realize a woman without man is like a house without a roof or a tree without branches"), just to name these few. (Ayafor, 2011, pp. 53-60).

This study is a follow-up of the one carried out by Ayafor (2011) in the sense that it still dwells on non-standard features in Anglophone Cameroonian literary works. However it differs from Ayafor (2011) in the sense that it focuses on idiomatic expressions, an area where these non-standard features abound and which has not been treated in the previous study. It is posited in this study that readers of novels practice consciously or unconsciously what is known as extensive reading and through the reading of these novels, they learn not only from the issues handled therein (corruption, nepotism, apartheid, moral depravity, etc.) but also the linguistic constructions (syntactic, grammatical, lexico-semantic) used by the authors. This concurs Scrivener (2005, p. 188) when he says:

There is a great deal of evidence that extensive reading has a powerful impact on language learning. The more someone reads, the more they pick up items of vocabulary and grammar from the texts, often without realizing it, and this widening knowledge seems to increase their overall linguistic confidence, which then influences and improves their skills in other language areas

Given that these Cameroonian writers are educated speakers of English who are in many cases English language teachers and whose novels are used in Cameroonian secondary and high schools, the tendency for the readers is to consider the linguistic constructions used by these writers as models to be emulated both in formal and non-formal situations. A scrutiny of the linguistic texture of many Cameroonian literary productions reveals that their writings embody a lot of non-standard idiomatic expressions. The questions to be answered in the study are the following: What are the various processes via which these non-standard idioms are created? Given that in the Cameroonian context, learners of English language are assessed on Standard British English, can the exposure of learners to these non- 
standard idioms be counterproductive to their learning of English? Can the exposure of English language learners to these expressions hamper the intelligibility of the writer with his readership? If that is the case, what measures should be taken by writers and English language teachers in order to cope with this situation?

\section{METhodology}

The data for the study was gathered after a complete reading of the novels. While reading the novels, attention was paid to the expressions which either sound local, or modified by language users. The expressions were identified and gathered. Each expression was scrutinized in order to find out the process through which it has been created (translated, coined or modified). The following dictionaries were used in order to check whether or not the expressions identified are attested either in Standard British English or in Standard Cameroon English.

1) ADOCEU: A Dictionary of Cameroon English Usage, 2007.

2) CALD: Cambridge Advanced Learner's Dictionary, 2005.

3) CEED: Chambers Encyclopedic English Dictionary, 1994.

4) CALDT: Cambridge Advanced Learner's Dictionary and Thesaurus, 2011.

5) HS: Harrap's Shorter, 2000.

As regards translated expressions, it was deemed necessary to get their donor home language expressions not only from the writers who has used the expression but also from the natives who belong to the same home language community with the writers so as to cross-check the uniformity of the donor language expressions. The expressions were classified under the following headings: idioms obtained from the translation home language expressions, coined expressions and the expressions obtained from the modification of Standard British English expressions. As concerns the choice of the literary works, it was judged impartial to include only the novels written both by male and female English-speaking Cameroonians of the two English-speaking regions of the country (Northwest and Southwest) of various linguistic and educational backgrounds. This implies that no literary work written by French-speaking Cameroonians and translated into English was included among the novels from which data was drawn. The novels from which the data was drawn are identified as follows: SNS: Son of the Native Soil (Ambanasom, 1999), FID: Flowers in the Desert (Afuh, 2005), TDH: The Deadly Honey (Kongnyuy, 2002), Nyuysham (Tardzenyuy, 2002), TWM: The Widow's Might (Nkemngong Nkengasong, 2006), NFM: A Nose for Money (Nyamnjoh, 2006), NWTD: No Way to Die (Asong, 1991), ALOTD: A Legend of the Dead (Asong, 1994a), SIH: A Stranger in his Homeland (Asong, 1994 b), COT: The Crown of Thorns (Asong, 1995), SC: Salvation Colony (Asong, 1996 a), TAF: The Akroma File (Asong, 1996 b , Chopchair (Asong, 1998), COB: The Craps of Bangui (Asong, 2005) and DFN: Doctor Frederick Ngenito (Asong, 2006). For the sake of clarity, the expressions will be presented in tables. The method of data presentation is descriptive and/or comparative. In other words, the expressions are first presented and clues about their meaning(s), donor language expressions (where applicable), their donor languages (where applicable) as well as the source of the expressions (i.e. the novel from which the expressions are drawn) are provided. As regards modified idioms, their Standard British English expressions are compared with the modified expressions so as to identify the elements which have either been added, substituted or deleted in the modified expressions. Also, the processes which govern the modification are provided (addition, substitution, deletion, etc.).

\section{DEFINITIONS OF IDIOMS AND REVIEW OF LITERATURE}

Idioms are "fixed phrases, consisting of more than one word, with meanings that cannot be inferred from the meanings of the individual words" (Fromkin and Rodman, 1988, p. 236). An idiom is "a phrase which has a distinct meaning [...] which cannot be explained from the separate meanings of the different words in the phrase" (Platt et al, 1984, p. 107). Idiomatic expressions can be "a catch phrase for opaque idioms, well-worn clichés, dead metaphors, proverbial sayings, [...]" (Kouega, 2000, p. 231). In effect, what is common to idiomatic expressions is that their meanings "cannot be accounted for as a compositional function of the meanings their parts have when they are not parts of the sequences" (Cruse, 1986: 37). As a whole, an idiom "is a group of words whose meaning cannot be explained in terms of the habitual meanings of the words that make up the piece of language (Todd, 1987, p. 87). He goes further to categorize idioms as follows: alternative comparisons (e.g.: dead as a dodo, good as gold), noun phrases (e.g.: a blind alley: route that leads nowhere, a red letter day: a day that will never be forgotten), prepositional phrases (e.g.: by hook or by crook: by whatever methods prove necessary), verb + noun (e.g.: kick the bucket: die), verb + prepositional phrase (e.g.: be in the doghouse: be in disgrace) and verb + adverb e.g.: (put down: kill) (Todd, 1987, pp. 86-87).

Idioms are lexico-semantic constructions which are very prolific in non-native English contexts. They are attested in many non-native varieties of English. Platt et al (1984, pp. 107-110) provides some examples of idioms in Papa New Guinean English (e.g., to be two-minded: to be in two minds, to be open-minded; to pass the hard times: to have a hard time, to pass a hard time, etc.), in Sri Lankan English (to put a clout: to give someone a clout; to put a telephone call: to make a telephone call; to put a feed: to have a good meal, etc.) in Singaporean and Malaysian English (to shake legs: to be idle), in Nigerian English (to declare surplus: to host a party), in East African English ( to be on the tarmac: to be in the process of finding a new job). Cameroon English is also rich in terms of idiomatic usage as the following examples 
listed in Kouega (2000, pp. 233-235) indicate: sons and daughters / all elements of (of a tribe): member of a tribe; come good: greeting addressed to a guest; catch you: leave taking utterance equivalent to "good bye"; I'm coming: I am going out now; excuse me: utterance made by an affected person in response to the utterance "sorry"; to throw water: to offer drinks; to be on seat: to be present in one's office; to chase a file: to speed up the processing of one's document; to put to bed: to have a baby; to give someone a snake beating: to beat somebody to. The sources of idiomatic variations in non-native contexts are many. In Nigerian English for instance, Adegbija (2003, pp. 48-49) has identified six sources, namely analogical creation (e.g. public dog), native source translation equivalents (e.g. to wet the ground), personality related (e.g. sidon look attitude), media instigated source (e.g. hidden agenda), slang origin (e.g. to flashy).

\section{DATA PRESEnTAtion AND ANALYsis}

The write-up on many Cameroon English literary works embodies a lot of non-standard idiomatic expressions. A scrutiny of these expressions reveals that they are created via several processes. Three major processes which govern the creation of these idioms have been identified and the expressions grouped as follows: idioms obtained via the translation of home language expressions, coined idioms and the idioms obtained via the modification of Standard British English expressions. As concerns the idioms obtained via the modification of Standard British expressions, it has been observed that the modification are obtained via substitution, addition and deletion. Also, it is worth indicating that more than one process is also involved in the creation these modified idioms (e.g. substitution and addition, addition and deletion, just to name these few). For the purpose of clarity, these expressions will be presented in tables. Table 1 includes the expressions which are obtained via the translation of home language expressions, Table 2 comprises the expressions which are locally coined while Table 3 is the presentation of the expressions which are obtained via the modification of Standard British English expressions.

TABLE 1:

IDIOMS OBTAINED FROM THE TRANSLATION OF HOME LANGUAGE EXPRESSIONS

\begin{tabular}{|c|c|c|c|c|c|}
\hline $\mathbf{N}^{\circ}$ & Idioms & Donor language expressions & Meanings & $\begin{array}{l}\text { Donor } \\
\text { languages }\end{array}$ & Sources \\
\hline 1 & $\begin{array}{l}\text { To vomit } \\
\text { one's heart to } \\
\text { somebody }\end{array}$ & $\begin{array}{l}\text { Lə (inf. marker) tr[h (throw)nti (heart) ghi (poss. } \\
\text { Marker) cəm(all) } \quad \text { ab回 (onto) yw回 (somebody }\end{array}$ & $\begin{array}{l}\text { to tell somebody all what } \\
\text { one knows about an } \\
\text { affair }\end{array}$ & Nweh $^{1}$ & $T A F$, p. 121 \\
\hline 2 & $\begin{array}{l}\text { To spit } \\
\text { in somebody's } \\
\text { face }\end{array}$ & 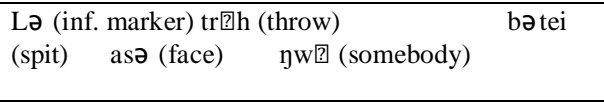 & to disgrace somebody & Nweh & COT, 32 \\
\hline 3 & To have heads & lə (inf. Marker) b团`y (have) atú (head) & to be reasonable & Nweh & COT, p. 47 \\
\hline 4 & $\begin{array}{l}\text { To throw excrement } \\
\text { into the face of } \\
\text { something /somebody }\end{array}$ & 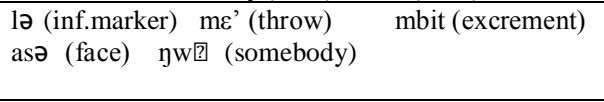 & to disgrace somebody & Nweh & $\begin{array}{l}A L O T D \\
\text { p. } 45\end{array}$ \\
\hline 5 & To have eyes and ears & 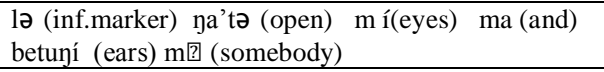 & $\begin{array}{l}\text { to be alert, vigilant, } \\
\text { reasonable }\end{array}$ & Nweh & $\begin{array}{l}\text { COT, } \\
\text { p. } 134 \\
\end{array}$ \\
\hline 6 & $\begin{array}{l}\text { To grind pepper on } \\
\text { somebody's head }\end{array}$ & yw回 (grind) só (pepper) tó (head) wa (somebody) & To beat somebody & Ngie $^{2}$ & $\begin{array}{l}S N S, \\
\text { p. } 67\end{array}$ \\
\hline 7 & $\begin{array}{l}\text { To open one's mouth } \\
\text { and talk }\end{array}$ & $\begin{array}{l}\text { lə (inf.marker) co’ (open) ncù (mouth) ysoy(talk) } \\
\text { ei (him/her) }\end{array}$ & to say nonsensical things & Nweh & $\begin{array}{l}\text { ALOTD, } \\
\text { p. } 202\end{array}$ \\
\hline 8 & $\begin{array}{l}\text { To drill books into a } \\
\text { child's head }\end{array}$ & $\begin{array}{l}\text { lə (inf.marker) yihi (put) akatei (books) atú } \\
\text { (head) ywa (somebody) }\end{array}$ & $\begin{array}{l}\text { To impart knowledge to } \\
\text { a child }\end{array}$ & Nweh & $\begin{array}{l}D F N, \\
\text { p. } 60\end{array}$ \\
\hline 9 & $\begin{array}{l}\text { To be sick in one's } \\
\text { Head }\end{array}$ & ləghua (illness) atú (head) & not being reasonable & Nweh & $\begin{array}{l}\text { DFN, } \\
\text { p. } 93\end{array}$ \\
\hline 10 & $\begin{array}{l}\text { To rub somebody } \\
\text { with excrement }\end{array}$ & $\begin{array}{lll}\begin{array}{l}\text { La } \\
\text { nj国 }\end{array} \quad \text { (rub) } & \text { jw回 } & \text { (take) mbit (excrement) } \\
\text { (somebody) }\end{array}$ & $\begin{array}{l}\text { to disgrace, disturb } \\
\text { somebody }\end{array}$ & Nweh & $\begin{array}{l}S I H, \\
\text { p. } 23\end{array}$ \\
\hline 11 & $\begin{array}{l}\text { To wash the genitals } \\
\text { of the chief }\end{array}$ & $\begin{array}{l}\text { lə (inf.marker) soh (wash) acena (sex/buttocks) } \\
\text { fua (chief) }\end{array}$ & $\begin{array}{l}\text { to have sexual } \\
\text { intercourse with the } \\
\text { chief }\end{array}$ & Nweh & $\begin{array}{l}\text { COT, } \\
\text { p. } 64\end{array}$ \\
\hline 12 & $\begin{array}{l}\text { To remove the } \\
\text { chair from under } \\
\text { somebody }\end{array}$ & $\begin{array}{l}\text { lə (inf.marker) c⿴囗口 ' (remove) alanya (chair) acèn } \\
\text { (sex/buttocks) } \quad \text { yw⿴囗 (somebody }\end{array}$ & to snatch the throne & Nweh & $\begin{array}{l}\text { COT, } \\
\text { p. } 98\end{array}$ \\
\hline 13 & To have four eyes & si (eyes) $\mathrm{kw \varepsilon}$ (four) & $\begin{array}{l}\text { to be a member of an } \\
\text { "evil society" }\end{array}$ & $\begin{array}{l}\text { Lamnso }^{3} \\
\text { and other } \\
\text { Grassfield } \\
\text { languages }\end{array}$ & $\begin{array}{l}\text { TDH, } \\
\text { p.138 }\end{array}$ \\
\hline 14 & To be four-eyed & si (eyes) kwe (four) & $\begin{array}{l}\text { to be a member of an } \\
\text { "evil society }\end{array}$ & $\begin{array}{l}\text { Lamnso and } \\
\text { other } \\
\text { Grassfield }{ }^{4} \\
\text { languages }\end{array}$ & $\begin{array}{l}\text { TDH, } \\
\text { p. } 60\end{array}$ \\
\hline
\end{tabular}

TABLE 1:

IDIOMS OBTAINED FROM THE TRANSLATION HOME LANGUAGE EXPRESSIONS (CONTINUATION)

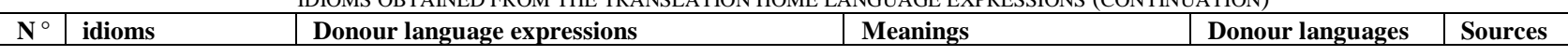




\begin{tabular}{|c|c|c|c|c|c|}
\hline 15 & $\begin{array}{l}\text { To see one's } \\
\text { flower }\end{array}$ & $\begin{array}{lc}\text { nə } & \text { y? (inf. Marker) fəla } \\
\text { tsjə } & \text { (persò (flower) }\end{array}$ & to menstruate & $\begin{array}{l}\text { Ghomala' } 5 \\
\text { and other } \\
\text { Grassfield languages }\end{array}$ & $\begin{array}{l}C O T, \mathrm{p} \\
145\end{array}$ \\
\hline 16 & $\begin{array}{l}\text { To know a lot of } \\
\text { books }\end{array}$ & $\begin{array}{l}\text { Ləbó (inf. marker + very) } \\
\text { (know) akatei (books) }\end{array}$ & to be highly educated & $\begin{array}{l}\text { Nweh } \\
\text { and other } \\
\text { Grassfield languages }\end{array}$ & $\begin{array}{l}\text { COT, p. } \\
64\end{array}$ \\
\hline 17 & $\begin{array}{l}\text { To have bad } \\
\text { mouth }\end{array}$ & 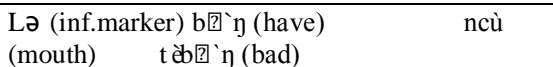 & $\begin{array}{l}\text { to say unpleasant things } \\
\text { about people }\end{array}$ & $\begin{array}{l}\text { Nweh, Grassfield } \\
\text { languages }\end{array}$ & $\begin{array}{l}S C, \mathrm{p} . \\
89\end{array}$ \\
\hline 18 & $\begin{array}{l}\text { To cry for } \\
\text { somebody }\end{array}$ & $\begin{array}{l}\text { Lə (inf. marker) l } \varepsilon \text { (cry) } \\
\text { (somebody) }\end{array}$ & $\begin{array}{l}\text { to organize a ceremony in } \\
\text { memory of a dead person }\end{array}$ & $\begin{array}{l}\text { Nweh, } \\
\text { Grassfield languages }\end{array}$ & $\begin{array}{l}\text { COT, p. } \\
82\end{array}$ \\
\hline 19 & $\begin{array}{l}\text { To give people } \\
\text { one mouth }\end{array}$ & ina' (to give) co (mouth) f $\varepsilon$ (one) & $\begin{array}{l}\text { to make them unanimous, } \\
\text { united, for a common cause }\end{array}$ & Ngie & $\begin{array}{l}\text { SNS, p. } \\
177\end{array}$ \\
\hline 20 & $\begin{array}{l}\text { Someone with two } \\
\text { hearts }\end{array}$ & wa (man) ne (with) fini (heart) bje' (two) & $\begin{array}{l}\text { someone who is not } \\
\text { unanimous with other people } \\
\text { of the group, a traitor }\end{array}$ & Ngie & $\begin{array}{l}\text { SNS, p. } \\
177\end{array}$ \\
\hline 21 & To buy one's head & Lə (inf. marker) 3 wə (buy) & $\begin{array}{l}\text { to bribe or give money to } \\
\text { somebody in order to avoid } \\
\text { or prevent a situation }\end{array}$ & $\begin{array}{l}\text { Nweh, } \\
\text { other } \\
\text { Grassfield languages }\end{array}$ & $\begin{array}{l}\text { TAF, p. } \\
132\end{array}$ \\
\hline 22 & $\begin{array}{l}\text { To expose one's } \\
\text { anus in the market }\end{array}$ & $\begin{array}{l}\text { Lə (inf. marker) cu (show) } \\
\begin{array}{l}\text { (sex/buttocks) } \\
\text { (market) }\end{array}\end{array}$ & $\begin{array}{l}\text { to expose one's private } \\
\text { problems, life; not to take } \\
\text { precautions }\end{array}$ & Nweh & $\begin{array}{l}\text { Chopch } \\
\text { air, } \\
\text { p. } 106\end{array}$ \\
\hline 23 & $\begin{array}{l}\text { To eat pepper } \\
\text { from somebody's } \\
\text { hands }\end{array}$ & $\begin{array}{l}\text { Ikod (inf. marker + eat) } \quad \text { úso (pepper) } \\
\text { abuge (hand) }\end{array}$ & $\begin{array}{l}\text { to be beaten severely by } \\
\text { somebody }\end{array}$ & Ngie & $\begin{array}{l}\text { SNS, p. } \\
19\end{array}$ \\
\hline 24 & $\begin{array}{l}\text { To look at water } \\
\text { on cocoyam } \\
\text { leaves }\end{array}$ & $\begin{array}{l}\text { inê (inf. marker + look) } \\
\text { (leaves) này (cocoyam) }\end{array}$ & $\begin{array}{l}\text { to have hopes which will not } \\
\text { be fulfilled }\end{array}$ & Ngie & $\begin{array}{l}S N S, \\
\text { p. } 48\end{array}$ \\
\hline 25 & $\begin{array}{l}\text { To receive one's } \\
\text { pay in a hat }\end{array}$ & $\begin{array}{l}\text { Inumo (inf. marker + take) } \\
\text { (money) ake (in) } \quad \text { day (hat) }\end{array}$ & to have a good salary & Ngie & $\begin{array}{l}\text { SNS, p. } \\
140\end{array}$ \\
\hline 26 & To sit on the stool & $\begin{array}{l}\text { Lə (inf.marker) yay (sit) } \\
\text { (chair) } \quad \text { lə fu? (chief) }\end{array}$ & to be crowned as the chief & $\begin{array}{l}\text { Nweh, Grassfield } \\
\text { languages }\end{array}$ & $\begin{array}{l}C O T, \mathrm{p} . \\
60\end{array}$ \\
\hline 27 & To sleep a woman & 1ә (inf.marker) noy (sleep) mə ywi (woman) & to have sex with a woman & $\begin{array}{l}\text { Nweh, Grassfield } \\
\text { languages }\end{array}$ & $\begin{array}{l}\text { SIH, p. } \\
279\end{array}$ \\
\hline
\end{tabular}

TABLE 2:

COINED IDIOMS

\begin{tabular}{|c|c|c|c|}
\hline $\mathrm{N}^{\circ}$ & Coined expressions & Meanings & Sources \\
\hline 28 & To have the mouth and ear of somebody & to be the emissary or representative of somebody & $C O T$, p. 175 \\
\hline 29 & To run before one can walk & $\begin{array}{l}\text { not to do things with a lot of anticipations, to be very } \\
\text { anxious }\end{array}$ & NFM, p. 82 \\
\hline 30 & To clean somebody's eyes & to flatter somebody & ALOTD, p.304 \\
\hline 31 & To oil somebody's hands & to bribe somebody & ALOTD, p.304 \\
\hline 32 & To rub somebody's mouth & to bribe somebody & SNS, p.143 \\
\hline 33 & To be born at the right moment & to be lucky, fortunate & $T D H$, p.143 \\
\hline 34 & To know each other as man and woman & $\begin{array}{l}\text { To have got the opportunity to see each other's nakedness } \\
\text { or nudity }\end{array}$ & Nyusham, p. 53 \\
\hline 35 & To burn one's (woman) womb & to become sterile & $F I D$, p. 66 \\
\hline 36 & To post a girl to somebody (man) & $\begin{array}{l}\text { to send her to live with a man as his wife without his } \\
\text { approval }\end{array}$ & NWTD, p.214 \\
\hline 37 & To put wings on something & to make it go fast & NWTD, p.95 \\
\hline 38 & To speak with so much vinegar on one's tongue & to speak violently & $A L O T D, \mathrm{p} .150$ \\
\hline 39 & To wash the male side of one's womb & to give birth to male babies & $C O T$, p.206 \\
\hline 40 & To be the only cock to crow & $\begin{array}{l}\text { to be the only person to give orders, the only person } \\
\text { whose voice can be heard }\end{array}$ & $T A F, p .84$ \\
\hline 41 & To be somebody's sperm & to be somebody's offspring & $C O B, p .145$ \\
\hline 42 & To be on somebody's neck & to request something from somebody persistently & $T W M, p .60$ \\
\hline 43 & To be somebody's first piss & to be somebody's first child & $D F N, p .131$ \\
\hline 44 & To sing a different song & to say different things & $D F N, p .132$ \\
\hline 45 & To walk on one's head & to be proud & $S I H, p .70$ \\
\hline 46 & To speak grammar & to speak an educated variety of English & $S I H, p .92$ \\
\hline 47 & To dig a woman & to have sex with a woman & $S I H, p .63$ \\
\hline 48 & To eat plantains every day & to have sex with the same partner every day & $N F M, p .20$ \\
\hline 49 & To have traffic jam in one's head & to be thoughtful & $F I D, p .132$ \\
\hline 50 & To drag the crown into the gutters & to alter the prestige of the crown & ALOTD, p. 222 \\
\hline
\end{tabular}

TABLE 3:

IDIOMS OBTAINED FROM THE MODIFICATION OF BRITISH ENGLISH EXPRESSIONS

\begin{tabular}{|l|l|l|l|l|}
\hline $\mathrm{N}^{\circ}$ & Modified expressions & Donour expressions & Lexes/morphemes affected & $\begin{array}{l}\text { Processes } \\
\text { involved }\end{array}$ \\
\hline
\end{tabular}




\begin{tabular}{|c|c|c|c|c|c|}
\hline 51 & $\begin{array}{l}\text { To bite the finger that fed } \\
\text { somebody }\end{array}$ & $\begin{array}{l}\text { to bite the hand that fed } \\
\text { somebody }\end{array}$ & finger $<$ hand & substitution & $S N S$, p. 69 \\
\hline 52 & Without mixing words & without mincing words & mincing $<$ mixing & substitution & $\begin{array}{l}\text { NWTD, p. } \\
186\end{array}$ \\
\hline 53 & $\begin{array}{l}\text { To put a full stop to } \\
\text { something }\end{array}$ & $\begin{array}{l}\text { to put an end to /a stop to } \\
\text { something }\end{array}$ & full stop $<$ end/stop & substitution & $\begin{array}{l}N W T D, \mathrm{p} . \\
216\end{array}$ \\
\hline 54 & $\begin{array}{l}\text { To put a final full stop to } \\
\text { something }\end{array}$ & $\begin{array}{l}\text { to put an end to /a stop to } \\
\text { something }\end{array}$ & final full stop<end/stop & substitution & $\begin{array}{l}N W T D, \mathrm{p} . \\
218\end{array}$ \\
\hline 55 & To fall cats and hens & to rain cats and $\operatorname{dog} s$ & hens $<$ dogs & substitution & $\begin{array}{l}A L O T D, \\
\text { p.256 }\end{array}$ \\
\hline 56 & $\begin{array}{l}\text { To cut one's goat } \\
\text { according to one's size }\end{array}$ & $\begin{array}{l}\text { to cut one's coat according to } \\
\text { one's size }\end{array}$ & goat $<$ coat & substitution & $C O B, 131$ \\
\hline 57 & $\begin{array}{l}\text { As sure as morning } \\
\text { follows night }\end{array}$ & $\begin{array}{l}\text { as sure as hell / as sure as eggs is } \\
\text { eggs }\end{array}$ & $\begin{array}{l}\text { morning follows night }<\text { hell / egg } \\
\text { is eggs }\end{array}$ & substitution & $D F N$, p. 43 \\
\hline 58 & $\begin{array}{l}\text { As you make ya bed, so } \\
\text { shall you die on it }\end{array}$ & $\begin{array}{l}\text { as you make your bed, so shall } \\
\text { you lie on it }\end{array}$ & ya $<$ your $/$ die $<$ lie & substitution & $S I H$, p.215 \\
\hline 59 & to sing someone's song & to sing someone's praises & song $<$ praises & substitution & $F I D$, p. 29 \\
\hline 60 & $\begin{array}{l}\text { to leave somebody to } \\
\text { himself }\end{array}$ & to leave somebody alone & himself $<$ alone & substitution & $C O T$, p. 64 \\
\hline 61 & $\begin{array}{l}\text { To put one's shoulder to } \\
\text { the plough }\end{array}$ & $\begin{array}{l}\text { to put one's shoulder to the wheel } \\
\text { or to put one's hand to the plough }\end{array}$ & $\begin{array}{l}\text { either } \\
\text { shoulder < hand } \\
\text { or } \\
\text { plough }<\text { wheel }\end{array}$ & substitution & $C O T$, p. 85 \\
\hline 62 & To be on night & to be on night call & $\begin{array}{l}\text { "call" is deleted in the modified } \\
\text { expression }\end{array}$ & deletion & $S I H, \mathrm{p} .85$ \\
\hline 63 & $\begin{array}{l}\text { To make a big name for } \\
\text { oneself }\end{array}$ & to make a name for oneself & $\begin{array}{l}\text { "big" is inserted in the modified } \\
\text { expression }\end{array}$ & addition & $\begin{array}{l}\text { NWTD, p. } \\
47\end{array}$ \\
\hline 64 & $\begin{array}{l}\text { To take the law in one's } \\
\text { own wicket hand }\end{array}$ & $\begin{array}{l}\text { to take the law into one's own } \\
\text { hand }\end{array}$ & $\begin{array}{l}\text { "wicket" is inserted in the modified } \\
\text { expression }\end{array}$ & addition & $\begin{array}{l}A L O T D, \mathrm{p} . \\
39\end{array}$ \\
\hline 65 & $\begin{array}{l}\text { To poke one's noxious } \\
\text { nose into something }\end{array}$ & to poke one's nose into something & $\begin{array}{l}\text { "noxious" is inserted in the } \\
\text { modified expression }\end{array}$ & addition & $\begin{array}{l}\text { Nyusham, } \\
\text { p. } 133\end{array}$ \\
\hline 66 & $\begin{array}{l}\text { Where there is a will, } \\
\text { there is always a way }\end{array}$ & $\begin{array}{l}\text { where there is a will, there is a } \\
\text { way }\end{array}$ & $\begin{array}{l}\text { "always" is inserted in the modified } \\
\text { English proverb }\end{array}$ & addition & $\begin{array}{l}\text { COT, p. } \\
182\end{array}$ \\
\hline
\end{tabular}

\begin{tabular}{|c|c|c|c|c|c|}
\hline 67 & To shout over somebody's head & to shout at somebody & $\begin{array}{l}\text { "at" is replaced with "over" } \\
\text { and "head" is inserted in the } \\
\text { modified expression }\end{array}$ & $\begin{array}{l}\text { substitution, } \\
\text { addition }\end{array}$ & NWTD, p. 46 \\
\hline 68 & To put one's feet into hot water & $\begin{array}{l}\text { to be in hot water or to get } \\
\text { into hot water }\end{array}$ & $\begin{array}{l}\text { "to be" or "to get" is (are) } \\
\text { replaced with "to put" and } \\
\text { "one's feet" is inserted in the } \\
\text { modified expression }\end{array}$ & $\begin{array}{l}\text { substitution, } \\
\text { addition }\end{array}$ & $\begin{array}{l}\text { Chopchair, } \\
\text { p.55 }\end{array}$ \\
\hline 69 & To have one's feet in water & to be in hot water & $\begin{array}{l}\text { "to be" is replaced with "to } \\
\text { have"; "one's feet" is inserted } \\
\text { into the modified expression } \\
\text { and "hot" is deleted in the } \\
\text { resulting expression }\end{array}$ & $\begin{array}{l}\text { substitution, } \\
\text { addition, deletion }\end{array}$ & COT, p.121 \\
\hline 70 & To have a good name & to make a name & $\begin{array}{l}\text { "make" is replaced with "have" } \\
\text { and "good" is inserted in the } \\
\text { expression }\end{array}$ & $\begin{array}{l}\text { substitution, } \\
\text { addition }\end{array}$ & $N F M$, p. 82 \\
\hline 71 & To be at somebody's very nose & $\begin{array}{l}\text { to be (right) under } \\
\text { somebody's nose }\end{array}$ & $\begin{array}{l}\text { "under" is replaced with "at" } \\
\text { and "very" is inserted in the } \\
\text { modified expression }\end{array}$ & $\begin{array}{l}\text { substitution, } \\
\text { addition }\end{array}$ & SNS, p.148 \\
\hline 72 & $\begin{array}{l}\text { one good turn always deserves } \\
\text { another }\end{array}$ & $\begin{array}{l}\text { one good turn deserves } \\
\text { another }\end{array}$ & $\begin{array}{l}\text { "always" is inserted in the } \\
\text { expression }\end{array}$ & addition & $\begin{array}{l}\text { Nyusham, p. } \\
153\end{array}$ \\
\hline
\end{tabular}

It is important to note that what is common with the expressions presented in Tables 1 and 2 is that they are drawn in the Cameroonian sociocultural context. As stated earlier, they are either obtained via the translation of home language expressions $(n=27)$ or via coining $(n=23)$. The reasons which might have motivated this lexical creativity can be linked to the need-filling motive (Hockett, 1958, p. 405) and the relexification of home languages or simply in the insufficient exposure of speakers to exonormative models. What is equally worth noting about these expressions is that almost all of them have not yet gained national currency. In effect, they are not yet integrated the dictionary of Cameroon English usage (Cf. Kouega's (2007) A Dictionary of Cameroon English Usage). With regard to modified idioms (n=22), it can observed from Table 3 that modification can be obtained via substitution $(n=11)$ (e.g. to bite the finger that fed somebody < to bite the hand that fed somebody, without mixing words < without mincing words), addition ( $\mathrm{n}=5$ ) (e.g. to make a big name for oneself < to make a name for oneself, to take the law in one's own wicket hand < to take the law into one's own hand), deletion $(\mathrm{n}=1)$ (e.g. to be on night < to be on night call), substitution and addition ( $\mathrm{n}=4)(\mathrm{e} . \mathrm{g}$. to shout over somebody's head < to shout at somebody) and finally substitution, addition and deletion ( $\mathrm{n}=1)$ (e.g. to have one's feet in water < to be in hot water). The modification of these idioms can be linked to the insufficient exposure of speakers to English exonormative models (Kachru, 1986:21). As concerns the domains under which these expressions fall, it can be said that they can be classified under the following lexical registers: sex, love and marriage; effrontery, 
cheek and unpleasant situations; appearance and description; administration, education and communication; money, finance and bribery as well as customs, traditions and magic.

At the present state of research these expressions can only be considered as non-standard features given that they are neither attested in Standard British English nor in the dictionary of Cameroon English usage. However, as usage constantly evolves, it is possible that these expressions gain national currency and gradually find their way in Standard Cameroon English usage.

\section{DiSCUSSIONS OF THE FINDINGS}

As mentioned earlier, the exposure of readers to these non-standard idioms can constitute a hindrance to their learning of English language. These idioms are either indigenized lexico-semantic constructions (idioms in Tables 1 and 2) which are either proper to the home language communities of the authors who use them or which have not yet gained national currency. The idioms presented in Table 3 (i.e. modified idioms) can simply be considered as errors in English language use which are due to the fact that the speakers are not sufficiently exposed to the native English norms. It is worth pointing out that as regards the use of Standard British English idioms in non-native contexts, language users, due to their insufficient exposure the native norms modify native English idioms through several means. The study carried out by Ishaq Akbarian (2003, p. 49) on the problems that Iranian learners of English as a foreign language face in the learning of English idioms is instructive in this respect. The researcher has grouped the problems faced by Iranian learners of English as a foreign language in the use of native English idioms under semantics, structural features (word order, syntactic, grammatical errors) and lexical errors (omission, addition and substitution of lexemes) (Ishaq Akbarian (2003, pp. 55-56) and drawing from the works of Henzl (1973) and Kellerman (1977) he has attributed these errors to the unpredictability of the figurative meaning of idioms, the use on non-interactive situations in the teaching of idioms to learners, the insufficient teaching of English idioms in non-native contexts, the variance in formality, colloquialisms, situational appropriateness of English idioms (Ishaq Akbarian, 2003, pp. 52-53).

It is important to indicate that as concerns the official languages to be taught in Cameroon, although the constitutions of 1972 and 1996 simply talk of English and French as being the official languages of Cameroon, there is, however, a common belief and practice among language teachers, planners, policy makers and students of English that the standard to be pursued is the Standard British standard because of the country's colonial and historical past (Ubanako, 2011, p. 230). Therefore, no room is given to indigenized constructions in formal situations, even Standard Cameroon English which is a documented variety of Cameroon English is not yet accepted by English language teachers in formal situations. This concurs Simo Bobda (2002, p. vi) when he points out that "while acknowledging the legitimate emergence of an autonomous variety of English in Cameroon, I believe that we are still, in many ways, dependent upon British and American norms. Our educational and professional successes are still determined by these norms". On the basis of the above clues, it is obvious that these non-standard idioms are considered as instances of wrong English usage by the English language teachers. Therefore, when they are spotted out in students scripts, English language teachers simply cancel them since they are instances of wrong usage. Students, to their greater dismay, are confused because these expressions which they use and for which they are penalised in their written examinations are used in the novels which they are constantly exposed to and these literary works are written by people who are either English language teachers or English-speaking Cameroonians who are universities postgraduates. For instance, Linus Asong, the author of The Crown of Thorns, Shadrack Ambanasom, the author of Son of the Native Soil, Nkemgong Nkengasong, author of The Widow's Might, Francis Nyamnjoh, the author of A Nose for Money, author of The Deadly Honey, Margaret Afuh, the authoress of Flowers in the Desert, just to name these, few are postgraduates. To be more precise, the first four authors are Doctorate Degree holders and University Professors. The novels of the first two authors are being used in the Cameroonian Secondary and High school of the Anglophone sub-system of education. The first three authors have taught English language in Cameroonian secondary schools for many years before starting teaching literature at the tertiary level of education (i.e. universities). The last novelist (i.e. Margaret Afuh) is an English language teacher. So, when Cameroonian English language learners read their works, they consider their English language use as the models to be emulated. They are confused when their English language teachers consider some of the idioms that they use and which are used in the novels of these writers as instances of errors. Why should English language learners be exposed to these non-standard idioms if these expressions are considered by English language teachers as errors in language use? In addition to the impact on English language learning, it can be asserted that these non-standard idioms can be the source of much unintelligibility between the writers and their readership. In effect, these expressions have not yet gained national currency in Cameroon. They can easily be understood by readers who belong the same language community with the authors. This is true of the expressions which are translated from the novelists' home languages and those which are coined. This therefore implies that even Cameroonians who do not belong to the same home language community will find it difficult to understand the meaning of these expressions. Consequently, the message conveyed by the authors can easily be obstructed by these expressions. What can therefore be done in order to cope with this situation?

Given that the Cameroonian educational system still relies on native English norms as regards the teaching of English language, in order to draw students attention on them (especially idioms translated from home languages and coined ones), writers should either provide in their novels footnotes or a glossary which explain the meanings of these non- 
standard expressions and they should indicate that the expressions are not native English expressions. Also, language specialists and educational authorities should design a dictionary of Cameroon English literary usage so as to put at the disposal of students a document which contains and explains the accepted Cameroon literary English lexes and expressions. By so doing, students will not be penalised any more for having used in their write-ups expressions which are used by Cameroonian writers in their literary works.

As regards modified idioms, it is important to indicate that these modifications more often than not are done unconsciously by the writers. They are therefore recommended to have their novels edited by professional editors before they publish them. In the course of editing them, the editors will spot out these modified idioms and will provide the Standard British equivalents. Given that some of these novels feature in the official list of novels to be used in Cameroonian secondary and high schools, while reading them in class with students, teachers should spot out the expressions and draw students' attention on the fact that these idioms are non-standard expressions and should therefore not be used in formal contexts (during official exams, test of English language proficiency (e.g.: TOEFL), formal letters, recruitment tests, just to name these few). Also, syllabus designers should make sufficient provision for the teaching of Standard British English idioms in the English language syllabus for secondary and high schools. This will urge teachers to prepare lessons on idiomatic expressions and design adequate materials for their teachings. This will facilitate the exposure of English language learners to Standard British English expressions.

\section{CONCLUSION}

From the foregoing study, it can be retained that various non-standard idioms abound in the write-up of Cameroonian writers of English expressions. Besides, it is found that several processes are put at work in the creation of these idioms. While some are obtained via the translation of home languages expressions, others are obtained via coinages and a sizeable proportion of them are obtained via the modification of Standard British English expressions. This lexicosemantic creativity has been attributed to factors such as the need-filling motive, the relexification of home languages and the insufficient exposure of speakers to exo-normative norms. Moreover, it has been demonstrated in the study that taking into consideration the fact that the Cameroonian educational system still depends on native norms, the exposure of English language learners to these non-standard expressions cannot only be counterproductive to their learning of English language but can also go a long way to hamper intelligibility between the writers and its readership. It is suggested in the study that writers should provide either footnotes or a glossary which explain non-standard expressions that they use in their literary works and draw readers' attention on the fact that they are non-standard English expressions. Also, they should have their works edited by professional editors before they have them published. English language teachers should attach a lot of importance to the teaching of Standard British idioms in their vocabulary lessons. This will make learners familiar with Standard British English expressions. Furthermore language researchers and educational authorities should work out a glossary or a dictionary of Cameroon literary English which will provide the entries of lexes and expressions accepted in Cameroon literary English so as to provide learners with a list of accepted lexes and idioms that they can use in their English language and literature tests.

Notes:

1-The Nweh language is a Bantu language spoken in the Southwest region of Cameroon.

2-The Ngie language is a Bantu language spoken in the Northwest region of Cameroon.

3-Lamnso' is a Bantu language spoken in the Northwest region of Cameroon

4-In Cameroon, Grassfield languages are the languages spoken in the West and North-west regions of Cameroon

5- Ghomala' is a Bantu language spoken in the West region of Cameroon

\section{REFERENCES}

[1] Adegbija, E. (2003). "Idiomatic Variation in Nigerian English.” In Peter Lucko et al. (Editors), pp.14-56, Studies in African Varieties of English. Frankfurt: Peter Lang.

[2] Afuh, M. (2003). Born Before her Time. Patron Publishing House.

[3] Ambanasom, S. (2007). Son of the Native Soil. Bamenda: Patron Publishing House.

[4] Ashaq Akbarian (2003). "On the Problematic Areas of Idiomatic Language". Language Forum. 29 (2): 49-78.

[5] Asong, T. L. (1991). No Way to Die. Bamenda: Patron Publishing House.

[6] Asong, T. L. (1994 a). A Legend of the Dead. Bamenda: Patron Publishing House.

[7] Asong, T. L. (1994 b). A Stranger in his Homeland. Bamenda: Patron Publishing House

[8] Asong, T. L. (1995). The Crown of Thorns. Bamenda: Patron Publishing House.

[9] Asong, T. L. (1996 a). Salvation Colony. Bamenda: Patron Publishing House.

[10] Asong, T. L. (1996 a). The Akroma File. Bamenda: Patron Publishing House.

[11] Asong, T. L. (1998). Chopchair. Bamenda: Patron Publishing House.

[12] Asong, T. L. (2005). The Craps of Bangui. Bamenda: Patron Publishing House.

[13] Asong, T. L. (2006). Doctor Frederick Ngenito. Bamenda: Patron Publishing House.

[14] Ayafor, M. (2011). "Non-Standard Features in English in Anglophone Cameroon NewWriting: Dilemmas for the Educational System”. English Today 107. 27 (3): 52-60.

[15] CALD (Cambridge Advanced Learner's Dictionary). (2005). Cambridge: CUP.

[16] CALDT(Cambridge Advanced Learner's Dictionary and Thesaurus). (2011). Cambridge: CUP. 
[17] CEED (Chambers Encyclopedic English Dictionary). (1994). Cambridge: CUP.

[18] CHAMBERS (Chambers Encyclopedic English Dictionary). (1994). Chambers: Cambridge.

[19] Fromkin, V. and R. Rodman. (1988). An Introduction to Language. 4th edition. New York: Rinehart and Winston, Inc.

[20] HS (Harrap's Shorter). (2000). Sixth edition. Edinburgh: Chambers Harrap Publishers LTD.

[21] Hockett, C F. (1958). A Course in Modern Linguistics. New York: Macmillan.

[22] Kachru Braj, B. (1986). The Alchemy of English. Illininois: University of Illinois Press.

[23] Kongnyuy E. (2002). The Deadly Honey. Yaounde: AMA-CENC

[24] Kouega, J-P. (2000). Aspects of Cameroon English Usage: A Lexical appraisal. PhD thesis, University of Yaounde I, Cameroon.

[25] Kouega, J-P. (2007). (ADOCEU) A Dictionary of Cameroon English Usage. Berne: Peter Lang.

[26] Lupson, P.P. and M.L. Pélissier. (1986). Everyday French Idioms. Chelttenham: Stanley Thornes Publishers.

[27] Nkemngong Nkengasong, J. (2006). The Widow's Might: Yaounde: Edition CLE.

[28] Nyamnjoh, F. B. (2006). A Nose for Monkey. Nairobi: East African Educational Publishers LTD.

[29] Platt, J. Weber H. and M.L. Ho. (1984). The New Englishes. London: Routledge.

[30] Schmied, J. (1991). English in Africa: An Introduction. London: Longman.

[31] Scrivener, J. (2005). Learning Teaching: A Guidebook for English Language Teachers. 2nd Edition. Oxford: Macmillan Publishers Limited.

[32] Simo Bobda, A. (2002). Watch your English: A Collection of Remedial Lessons on English Usage. 2nd ed. Yaounde: B\&K Language Institute.

[33] Todd, L. (1987). An introduction to Linguistics. Essex: Longman.

[34] Ubanako Njende, V. (2011). "Pedagogic Implications of Regionally-Determined Varieties of Cameroon English". Changing English 18(2): 229-238.

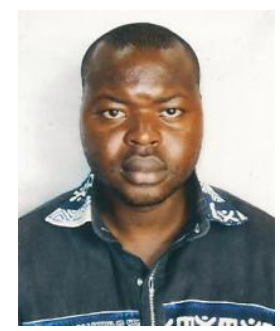

Lozzi Martial Meutem Kamtchueng was born in 1983 in Bafoussam, Cameroon. He is a holder of two diplomas in English and French language teaching (DIPESI, 2004 and DIPES II, 2006) from the Higher Teachers' Training colleges of the University of Yaounde I, Cameroon as well as a BA (Bilingual LettersEnglish and French), a Maitrise (English Language Studies, 2006), a DEA/Master's Degree (English Language Studies, 2008) and a $\mathrm{PhD}$ (English Language Studies, 2013). He is interested in English language use in non-native contexts, language teaching and contrastive studies. Presently, he is a senior Lecturer in English Linguistics in the Department of Bilingual Letters of the University of Maroua, Cameroon. 